\title{
THE EFFECT OF CORONA VIRUS ON THE GLOBAL CLIMATE
}

\author{
Sri Rahayu Pudjiastuti ${ }^{a *}$, Sopian $^{a)}$, Nestiyanto Hadi ${ }^{a)}$ \\ a) STKIP Arrahmaniyah, Depok, Indonesia \\ ${ }^{*}$ Corresponding Author: yayu.pudjiastuti@gmail.com
}

Article history: received 12 August 2020; revised 28 August 2020; accepted 03 September 2020

\begin{abstract}
The Covid-19 pandemic has worried the international community. Countries in the world have banned their citizens from leaving their homes, to avoid transmission of the corona virus. Based on this policy, indirectly it has an effect on air pollution. The earth is clean again with an appeal to just stay at home. The corona virus has changed people's views on climate change. Although on the other hand the corona virus has had a negative impact on global economic conditions. This study aims to provide an overview and analysis of the effect of corona on the global climate. This research method uses a descriptive analysis method supported by secondary data and literature studies. Climate can affect the stability of covid-19, the corona virus can be stable at temperatures of $1{ }^{\circ} \mathrm{C}$ to $10^{\circ} \mathrm{C}$ with a humidity of $40 \%$ to $50 \%$. Indonesia, which is located on the equator with an average temperature of 27 to $30^{\circ} \mathrm{C}$ and humidity of $70 \%$ to $95 \%$, is an area that is not ideal for the Covid-19 epidemic. However, the facts show that cases of Covid-19 have spread in Indonesia. This means that the population mobility factor has more influence on the development of Covid-19 in Indonesia. Thus it can be concluded that air temperature and humidity can be the dominant factors for the spread of the corona-19 virus. Thus the spread of the Covid-19 epidemic can be controlled by climate and weather factors, human demographics and mobility, as well as social interactions, and also determines public health interventions..
\end{abstract}

Keywords: covid-19; corona virus; global climate

\section{INTRODUCTION}

The Covid-19 pandemic, which has spread globally, will impact and threaten the lives of citizens both economically and socio-culture, but under different conditions, global climate change offers encouraging hope. For some time to come, extreme weather events, occurrence of ecological degradation and rising temperatures, could intensify the threat to human health posed by the virus. In previous epidemics, changes in weather and climate, rainfall and humidity can all contribute to the spread of infectious diseases. The occurrence of climate change can prolong the transmission of the corona-19 virus epidemic, both through vectors and through its geographical reach.

Environmental damage caused by policy making, governance and consumerism culture, shows that our earth is sick. Natural disasters occur because of the imbalance of the earth. Pudjiastuti [1] in his study explains that the management and utilization of forest natural resources, especially wood which is not optimal, causes the independence of regional development to be realized, due to the low quality of human resources and natural resources owned by several autonomous regions of different types, so that regional development depends on the central government. Policies for management and utilization are still overlapping, inconsistent and out of sync at various levels, thus opening opportunities for investors and unscrupulous officials to practice $\mathrm{KKN}$, and weak law enforcement and national management systems in the management and utilization of natural forest resources, especially timber [2]. The main problem of the environment is basically a problem faced by humans themselves, because in fact it is the human mind that realizes the existence of the universe [2].

Coronavirus appears at times of extreme climate change. While there is no solution to reduce the rate of climate change, new problems arise that require ecological and social carrying capacity. According to the Ministry of Ecology and Environment, the ratio of good air quality increased by $11.4 \%$ over the same time last year in 337 cities in China. In Europe, satellite imagery shows nitrogen dioxide $\left(\mathrm{NO}_{2}\right)$ emissions fading over northern Italy. The same phenomenon occurs in Spain and England. The facts show that there are big and very fast changes, due to the sudden and existential threat of the Covid-19 virus. The emergence of the Covid-19 pandemic has an impact on millions of people losing their jobs and being threatened with their future. Economic activity stops, stocks plummet, while carbon emissions also fall. This is the advantage of the sustainable, carbonless economic campaign that many people have wanted so far. The global pandemic that has taken human life should not be a solution to restore a pollution-free environment.

According to Kimberly Nicholas, a sustainable science researcher from Lund University in Sweden, explained that the number of carbon emissions from transportation appears to fall in countries that have policies to limit the activities of their citizens outside the home. Using vehicles and flying is the biggest contributor to emissions from the element of transportation, namely $72 \%$ and $11 \%$ from greenhouse gases and emissions, at the time of this pandemic it fell to $23 \%$ of total global carbon emissions. During a pandemic and policies for activities at home only, these emissions will remain low [3]. 
Nicholas explained that, if changes due to the effects of this pandemic persist until the outbreak ends, then emissions levels will remain low. But it could also be the other way around. People think of postponing all their travels, and will do so later after the pandemic is over. If this happens there will be no reduction in emissions. The corona virus has claimed many victims, lives, mental health, jobs, the economy, but there is a wisdom behind this condition, to look after and help each other, by just doing activities at home, reducing carbon emissions, which is very valuable to face climate change. This is not the first time that the epidemic has affected carbon dioxide in the atmosphere. Since before the industrial era, the spread of epidemics has always been associated with lower emission levels. In the 14th century Julia Pongratz discovered that the black plague epidemic in Europe and the smallpox epidemic that the Spanish colonizers brought to South America in the 16th century succeeded in reducing $\mathrm{CO}_{2}$ levels in the atmosphere. This fact was discovered by Pongratz by measuring small air bubbles trapped in ancient ice cores. This change is the result of the high mortality in genocide cases during the American conquest [4]

With so many casualties, it means that many agricultural lands are left by their owners and overgrown with wild plants which will reduce $\mathrm{CO}_{2}$ levels massively. The impact of this outbreak is estimated to be many deaths, and will affect land use changes. The current environmental effects are similar to the effects of the economic crisis in 2008 and 2009. According to Pongratz, at that time the global emission level had decreased for one year. At that time, the reduction in emissions occurred due to a lack of industrial activity, which contributes to carbon emissions as well as transportation. Combined emissions from industrial processes, manufacturing and construction account for $18.4 \%$ of global emissions that come from human activities. The crisis has reduced emissions by $1.3 \%$. However, when economic conditions recovered in 2010 , the emission rate increased again, reaching the highest in history.

"It is possible that Covid-19 could have the same effect," For example; the demand for products made from oil, iron and metals has decreased. But under the same conditions, the supply of raw materials is still high, so production can immediately follow. There are factors that can affect emission levels, that is, how long it will take for the corona virus pandemic to end. "This condition is difficult to predict." It is possible that we can see a long-term and substantial impact. If the corona virus pandemic continues until the end of the year, consumer demands will remain low, because they still lose income. world and fuel use cannot immediately recover. OECD estimates that the global economy can still grow in 2020, although it is estimated that growth will decline by $50 \%$ due to the corona virus- 19 . However, Glen Peters stressed that global emissions in 2020 are expected to fall by $0.3 \%$. Still lower than during the crisis in 2008-2009. It is possible to bounce back, but nevertheless not as hurry $\mathrm{r}$ first, if efforts to restore the economy were focused on the renewable energy sector [5]. In 2017 Nadieh Bremer and Shirley Wu, explaining how the earth breathes, these two figures have conjured up data on a certain time scale in digital visualization, based on satellite projections that measure the level of vegetative health on earth. This digital map shows the level of greenness on earth for the last four seasons. A visual animation called Breathing Earth gives the impression that the earth is breathing [6]. This condition is a projection from the earth, which can breathe again in the midst of the corona virus- 19 pandemic outbreak. The level of pollution on earth has dropped drastically. This clean air can save 73,000 people who live on earth. The number is greater than the number of victims due to the corona virus-19. "There is plenty of evidence to suggest that breathing polluted air has a major contribution to premature death, so the dilemma arises whether lives are saved from Covid-19, whether to survive so that pollution can be reduced, said Marshall Burke, an environmental resources economist. from Stanford University [7]. Actually this is not something new, because the results of research explain that: air pollution can reduce global life expectancy by cutting three years of human life chances. Environmental experts have often conveyed the threat of global warming. who have a skeptical view that this corona virus pandemic is a solution to the climate change crisis. The corona virus pandemic is an urgent threat, depending on whether we have or do not have the ability to respond. But just like a pandemic, climate change must also be our priority. The difference can be climate change plan, make program, very dependent on politicians and government policies, ideally pay attention to the warning scientists who have sounded the alarm. Likewise with the results of the study from Pudjiastuti which explains that environmental care programs can be realized well if they are supported by four basic elements, namely; environmentally friendly institutional policies, implementation of environment-based curricula, participatory-based environmental activities, and management of environmentally friendly supporting facilities. The environmental care program is basically the formation of pro-environmental attitudes and behaviors, including waste management that applies the $3 \mathrm{R}$ principle (reuse, reduse, recycle) to reuse goods, reduce consumption of goods, and recycle goods that are no longer used [8]

\section{RESEARCH METHODS}

This study uses a qualitative approach that focuses on the general principles that underlie the manifestation of symptom units that exist in social life. The discussion in this study was carried out through descriptive analysis supported by secondary data and literature studies [9]. This research is in the form of a case study that prioritizes research by investigating phenomena and their interrelated context and utilizing a lot of evidence or information to search for data [10].

\section{RESULTS AND DISCUSSION}

On March 26, 2020 BMKG and the research team conducted a press release informing the President and relevant ministers that there are indications of the impact of 
weather and climate in supporting the spread of the COVID19 pandemic. In a study entitled "The Impact of Weather and Climate on the Corona-19 Virus Outbreak" BMKG explained that the Corona-19 Virus cannot survive in a tropical climate that has high humidity temperatures like Indonesia. Dwikorita Karnawati as the Head of BMKG explained that BMKG also used references with peerreviewed status in 2011 in connection with the SARS Covid pandemic that had occurred previously. In reference to the results of this study, it is explained that the spread of this virus is controlled by high latitudes, namely temperatures with low humidity. Dwikorita explained that the reference he obtained in the BMKG study entitled "Climate Impacts on the Spread of the Corona-19 Virus" was the result of a new analysis carried out from January to March 2020.

In 1859 Charles Darwin sparked a theory contained in his book The Origin of Species. Darwin's theory is very relevant to current conditions, related to who causes the infection and who can heal the earth. The Covid-19 virus pandemic that has spread throughout the world has worried all people globally. The Covid-19 virus, which is transmitted through bats and pangolins, is spreading in Wuhan China. In December 2019 there were 1,274,346 people who had been infected with the Covid-19 virus and 69,480 people who had died [11]. When Charles Darwin revealed his theory of evolution, scientists were stunned. Biologists from England presented the theory of creation and the theory of evolution at a time when the world was concerned with religion. And at that time scholars questioned the concept of life on earth. After the emergence of Darwin's theory, questions arose from researchers who asked about machines that could move the universe by carrying out natural selection. This question was answered after 31 years the French scientist, Hugo deVries, continued Darwin's theory and discovered how living things could survive through natural selection. In 1909 William Johannsen a botanist from Denmark, called it a gene mutation. William Johannsen shortened it from "pangennes" which Darwin introduced, and deVries shortened it again to "pangene". Changes in temperature that get a natural response from living things are called adaptation through gene mutations, according to the theory of Darwin to Dobzhansky, also related to viruses and all microorganisms. Due to human activity, all animal and forest creatures that become hosts and their habitat are slowly disappearing. In the end, in order to survive, they look for new hosts. The closest mammals are humans. We call it disease. It is as if the virus attacks us innocent. In fact, we are the ones occupying them. Because the covid-19 virus generated by birds, bats and marine animals and pangolins that spread in Wuhan is not an attack, but the virus enters the human body because they fight for living space in the context of natural selection.

The occurrence of climate change is unpredictable, as is the spread of the virus. This is due to the increasing complexity of human activity and the interaction between climate and nature. However, annual fluctuations in seasonal flu virus infections, historical epidemics and yellow fever are some examples. The Intergovernmental Panel on Climate
Change, argues that $1 .{ }^{\circ} \mathrm{C}$ of global warming is caused by human activities. If global warming continues, temperatures could reach $1.5^{\circ} \mathrm{C}$ above this level in 2030 and 2052. The impact will be more frequent extreme weather, such as droughts, floods and heat waves. The occurrence of this extreme weather will result in changes in temperature and rainfall and humidity will have a knoc-on impact on animals and ecosystems.

Species that are susceptible to extreme weather are virus-carrying animals that can infect humans, and have the potential to do so, and insect vectors can also transmit. Although there is no evidence that climate change has an effect on the civid-19 pandemic, there are differences of opinion on whether climate change is affecting weather patterns. However, there is a lesson that we can get regarding future changes related to human activities that are affected by climate change. It is possible for viruses to move from wild species to humans. Like the Covid-19 pandemic, an infection caused by the novel SARS-CoV-2 corona virus, the spread of these viruses can cause new diseases and humans have the immunity to fight them.

WHO as a world health organization reports that "Climate change, which is a change in the global environment that is currently occurring, will affect the spread of infectious diseases in humans." The following is the mechanism for the spread of the virus; (1) Insect vector. For example, mosquitoes, sand flies and fleas are insects that can transmit cold-blooded viral infections, this means the virus cannot regulate their body temperature, hence external fluctuations. Increasing the extreme temperatures could remove insect vectors, however, could be of benefit to smaller and incremental increases

(2) animal host. Diseases transmitted from animals to humans and vice versa are known as zoonoses. An article published in the journal Annals of the American Thoracic Society explains that if climate change displaces wild animals, these animals will carry zoonoses with them. Emerging Infectious Diases reported that the outbreak due to increased rainfall in Los Santos in September and October 1999, has been the cause of the increasing rodent population. The amount of rainfall can also be the cause of the spread of enteroviruses which affect millions of people in the world. Humans spread enterovirus, poliovirus, coxsackie, and echovirus, to others via fecal-oral. Climate change can result in flash floods and carry waste into the ocean. When this happens, it is possible that the virus will contaminate marine animals, which are then consumed by humans, thus causing disease for humans.

(3) Human habits, a report from the CDC (Centers for Disease Control and Prevention) states that three out of every four emerging diseases originate from animals. The results of the study published in Natute stated that the corona virus was not made from a laboratory as revealed by conspiracy theories. COVID-19 originated in the Huanan wet market in Wuhan province, China, where traders of wild animals whose meat are consumed. This statement is consistent with the theory that explains the virus spread to humans from bats via pangolins sold in the Huanan market. 
Although it is not specific if climate change affects the emergence of COVID-19, it is possible to have an influence on human activities that bring in wild animals and have closer contact, especially when food supplies are limited. If the harvest fails, there is flood, drought, pests appear, the impact is starvation. This will cause humans to hunt and eat wild animals. Damage to forest ecosystems, illegal logging can also cause the virus to jump to wild animals and to humans.

(4) the immune system. In October and May and peaks in January and February the influenza epidemic occurs in northern latitudes. Warm weather reduces the spread of flu, presumably because people tend to gather indoors in large groups. Warmer and humid conditions can reduce the viability of the respiratory virus. Thus climate change could cause seasonal outbreaks to the north, where it is cooler and drier. There is no scientific agreement that warm conditions will result in a more or less severe flu epidemic. But climate change could have a more subtle effect. A paper published in PLOS Currents: explains that mild winters can reduce herd immunity, as fewer people contract the virus. In the following year, the virus will spread more easily and as a result the outbreak will get worse. The results of a study published in IOP science warn that rapid temperature fluctuations, characteristic of global warming, can inhibit the immune system from fighting respiratory infections. The researchers found that the rapid changes in weather in the fall were associated with a more severe flu outbreak the following winter. The immune systems of children and older adults appear particularly susceptible to rapid temperature changes. It is made clear by doctors in a paper in the Annals of the American Thoracic Society that an increase in pneumonia in children in Australia is associated with a sudden drop in temperature.

According to research conducted by Melanie Bannister, based on data on the spread of COVID-19 in 46 countries (excluding Indonesia) as of February 29, 2020, the temperature suitable for the development of COVID-19 is in the temperature interval of -5 to $10^{\circ} \mathrm{C}$ [12].

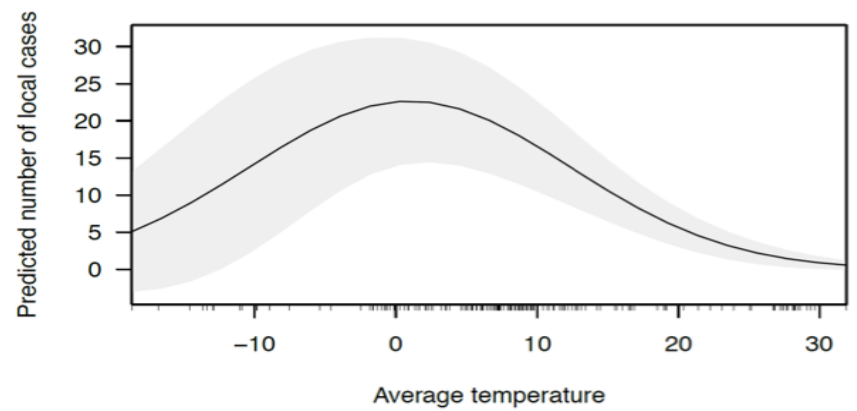

Figure 1. Predicted Cases of the Spread of COVID-19 at the Local Level [1]

Based on the graph above, Indonesia's condition is in a favorable position, because Indonesia's territory is at an average temperature above $25^{\circ} \mathrm{C}$. But Melanie Bannister revealed that the results of this study are only a preliminary study due to limited COVID-19 data at the global level. A similar explanation was delivered by Marco, who explained that the increase in COVID-19 cases at the global level was not influenced by climate factors. The reason is that this virus mutates quickly, and can adapt to the local climatic conditions of the affected area. The two results of this study have not been credible and are still not peer-reviewed.

BMKG (Meteorology, Climatology and Geophysics Agency) together with 11 doctors and professors from UGM in March 2019 presented the results of their study with the hypothesis that weather and climate conditions affect the spread of the Novel Corona Virus Disease (COVID-19) [13]. This research also explains that the tropical climate can minimize the spread of the corona virus. However, it is questionable whether the climate in Indonesia cannot make the corona-19 virus survive. The corona-19 virus shows a significant development pattern in cold and dry regions. Previously, it was widespread that SARS-CoV-1 was associated with a similar climate. Research shows that areas with dry and cold climates will be in demand by the corona virus, while areas with humid and tropical climates are predicted to inhibit the development of the corona virus. But the fact is that cases of corona virus-19 are spread throughout the world. With various kinds of COVID-19 cases that have appeared in tropical areas or areas with four seasons. This fact has rejected all hypotheses that explain that the corona virus cannot survive in a tropical climate. The COVID-19 cases that are widespread in tropical subSaharan Africa, Latin America and Southeast Asia make the fact that climate factors have no effect on the spread of COVID-19. For this reason, the assumption of the spread of the epidemic in the tropics is due to demographic factors and the mobility of people as predictors of its spread. Climate and weather factors are not relevant for assuming the spread of COVID-19.

The analysis conducted by BMKG and UGM states that the results of statistical analysis and mathematical modeling assume that climate and weather as supporting factors in the case of this outbreak developed in the first outbreak in a country or region with high latitude, but not a determining factor for the number of cases, especially after the outbreak. the second wave. In Indonesia, the case of the spread of the COVID-19 outbreak in the 2nd wave is more influenced by human mobility and social interactions. With geography, climate and weather conditions in Indonesia, the risk of the spread of corona virus-19 should be relatively lower. However, the fact is that there has been a jump in cases of corona virus-19 starting early March 2020. The recommendation of the BMKG and UGM team by considering the facts and results of the study from previous research emphasized that, if human mobility and social interaction are limited, it is accompanied by public health interventions Luo et .al 2020 and Poirier et.al.2020), then climate factors and air humidity can be supporting factors in mitigating the spread of the corona-19 virus. Furthermore, it is necessary to be aware that in parts of Indonesia there will be a change of seasons, which usually will also spread an outbreak of dengue fever. For this reason, the community should always maintain health and increase body immunity, through the use of climate so that they can be active and 
exercise at the right hour, besides maintaining distance and limiting mobility by remaining at home, accompanied by public health interventions, as a measure to mitigate the spread of the plague. COVID-19 more effectively. Because the weather is actually favorable, it will not be optimal without applying all these efforts more fully and effectively.

Eco Watch describes the effects of climate change on public health [14]:

1. There is air pollution which annually kills 7 million people in the world.

2. Improved air quality is one of the advantages of the corona virus

3. Infectious diseases $70 \%$ originate from environments where humans have a lot of contact with wild animals.

4. Climate and weather are factors that help spread the Covid-19 pandemic, not as a factor.

Araujo and Naimi [15] estimate that through a mathematical model involving demographic conditions and human mobility it can be concluded that the tropical climate can inhibit the spread of the corona virus, because a tropical climate can make the corona virus unstable more quickly. The results of previous studies indicate that countries with high latitude positions can be vulnerable to the spread of the corona virus-19 which is higher than tropical countries (Araujo [15]; Chen [16]; Wang [17]). The results of this study illustrate that the ideal condition for the corona virus is a temperature of 8 to $10^{\circ} \mathrm{C}$ with a humidity of 60 to $90 \%$ according to the research of Chen [16]. These researchers have concluded that the combination of temperature, humidity and weather and climate affects the spread of the corona virus-19. Cold and dry temperatures are environmental conditions conducive to the survival of the corona virus. The results of the research by Bannister-Tyrrell [18] prove that there is a negative relationship between temperatures above $1{ }^{\circ} \mathrm{C}$ and the number of suspected cases of corona virus per day. This research also proves that the corona virus-19 has an optimal distribution at very low temperatures, namely 1 to $9^{\circ} \mathrm{C}$. Which means that the higher the temperature, the lower the suspicion of daily corona virus-19 cases. The assumption of the number of cases of corona virus-19 based on the average air temperature during the period of the first case to 29 February 2020 is in a gray area with a confidence level of $95 \%$ of the predicted value.

With a temperature range of 1 to $9^{\circ} \mathrm{C}$ it is assumed that there are about 19 to 24 cases per day, with a temperature range of 10 to $19^{\circ} \mathrm{C}$ it is assumed that there are about 7 to 18 cases per day. However, this is not the case in Australia where the current summer conditions have a number of corona virus victims of around 5,000 people on April 3, 2020, this shows a fantastic number of cases. explained that in temperate climates, the influenza virus is closely related to a decrease in air humidity. Furthermore, Wang [17] also explained that similar to the influenza virus, this corona virus tends to be more stable in cold and dry temperature environments. Cold and dry air situations can weaken a person's host immunity, which results in the person being more susceptible to coronavirus, according to the study of Wang [17] Furthermore, Sun explained that low temperatures have an effect on the system human immunity. From a literature review, proved that the effect of low temperature $\left(<12{ }^{\circ} \mathrm{C}\right.$ or $<20{ }^{\circ} \mathrm{C}$ for water temperature $)$ on the human body can increase the production of stress hormones (cortisol). It is further explained that exposure to low air temperatures can increase hormone production and affect the function of immune cells in the body. However, in order to produce a hormonal response that affects immune cells, the body must be exposed to certain degrees of temperature. This hormonal response was not observed at exposure temperatures $>23{ }^{\circ} \mathrm{C}$. This analysis is reinforced by the results of previous research with the SARS CoV case (Chen [16]), it is made clear that in temperature conditions with high humidity it has a synergistic effect on the inactivity of the corona virus-19. From the results of the hypothesis it states that cases of respiratory tract infections will increase in winter.

Research by Chan [16] above also wrote that in the case of SARS CoV, viruses originating from respiratory droplets will last more than five days at a temperature of 22 to $25^{\circ} \mathrm{C}$ with humidity in the range of 40 to $50 \%$, especially viruses that stick to smooth surfaces. . This temperature situation is like the temperature in an air-conditioned room. However, the virus quickly disappears at an air temperature of $38^{\circ} \mathrm{C}$ with a humidity of $95 \%$. In tropical countries, it turns out that conditions are prone to exposure to the covid19 virus. Based on the results of research from Boston Children's Hospital which used case data from China, which was conducted on January 23 to February 10, explained that; It is not only climate and weather factors that can reduce the corona-19 virus, but there must be extensive policy interventions on public health.

This is also evident in the case of Covid-19 in Indonesia. With weather and climate conditions in Indonesia which are generally characterized by high temperatures and humidity, the Covid-19 case should not have developed. This is proven from January to February 2020 Indonesia is an area that tends not to be ideal for the Covid-19 outbreak in the 1 st wave. However, in reality in the 2nd wave from March to now, the Covid-19 case has hit Indonesia to the point where it reaches a number. cumulative 2000 in April 2020. This illustrates that climate and weather factors are not the only causes of the spread of covid-19, but non-weather has a greater role in the spread of covid-19 in wave 2 from January to February 2020. This phenomenon shows that there is a human-to-human transmission factor in the spread of the Covid-19 disease, such as the incident in Wuhan. it turns out that transmission has more influence than climate and weather factors in the 2 nd wave. From the results of the analysis of climate and weather conditions in Indonesia from January to March 2020 , the average value is $27^{\circ} \mathrm{C}$ to $30^{\circ} \mathrm{C}$. Apart from seasonal factors, the spatial variation of the average air temperature from one region to another is also influenced by topographic factors.

A place with a higher elevation than sea level will generally have a lower air temperature. In April to June 2020, it is estimated that the air temperature in Indonesia is estimated to be an average of $26^{\circ} \mathrm{C}$ to $29^{\circ} \mathrm{C}$. In July to 
September 2020, it is estimated that an average of $26^{\circ} \mathrm{C}$ to $28^{\circ} \mathrm{C}$. The average air temperature, which is lower than the previous months, is a natural thing, considering that the southern part of Indonesia has started to enter the dry season. The dry season in Indonesia is synonymous with the lack of clouds. Although this results in an increase in surface air temperature during the day, the temperature will quickly drop and the value will be lower at night until early morning. As a result, if this value is averaged on a daily basis, the daily average temperature obtained will be relatively lower than the months in the rainy season. Analysis of relative humidity $(\mathrm{RH})$ near the surface during January to February 2020 illustrates humidity values averaging $70 \%$ to $95 \%$ and relatively less than $85 \%$ were observed in Java, Bali and East Nusa Tenggara.

In April to September 2020, the humidity in Indonesia following a spatial pattern is estimated to have various variations according to time. However, in this period it is estimated to be around 60 to $80 \%$. Relatively lower humidity compared to other regions in Indonesia generally occurs in Java, Bali, Nusa Tenggara, western and southern Kalimantan, and southern Sulawesi to Maluku. It is estimated that the average upper air temperature and lower relative humidity in April 2020. Looking at the forecast climate conditions in April to August 2020, it shows that there is an increase based on the results of previous studies (Wang [17]) that can reduce the spread of covid-19. In general, Indonesia enters the dry season during this month with a sign of reduced cloud coverage which affects temperature and humidity, namely increasing the maximum daytime temperature to $360 \mathrm{C}$ with high humidity.

This condition is expected to benefit Indonesian regions which can naturally hinder the development of Covid-19. Based on the results of the study by Wang [17], the effective reproductive number (R) as a function of temperature and humidity, in Wuhan and in Jakarta from January to December, with social control conditions equivalent to Wuhan. One can observe the effective reproductive number $(\mathrm{R})$ between Wuhan with black stripes and Jakarta with red stripes from January to December. Draw the ratio of $\mathrm{R}$ Jakarta to $\mathrm{R}$ Wuhan with the same prediction of social control. This can be seen throughout the year that the ratio of $\mathrm{R}$ Jakarta / $\mathrm{R}$ in Wuhan is smaller 1. If social control can be strictly exercised in Wuhan, the rate of increase in cases is represented by an increase in the effective reproductive number $(\mathrm{R})$ which is estimated to have a value of 0.5 to 0.9 times the rate. conditions for the increase in Wuhan cases.

For the record: this number must be interpreted with caution because restrictions on social mobility remain the key to the emphasis of the Covid-19 case and the World Health Organization (WHO) has explained that Covid-19 can live in a tropical climate. effective reproductive number (R) between Wuhan and Jakarta from January to December. The air quality situation based on the 10 micron particulate matter observation graph illustrates the value that is not different after WFH (work from home) when compared to before. It should be noted that on March 13, 2020 a policy was set to close schools for the DKI Jakarta area. There is a surge in PM10 in Kemayoran from March 14 to 152020 with an indicator of no direct population activity. It is predicted that at that time people panicked, panic buying occurred in several super markets. During the weekend March 21 to 22, after WFH, there was a significant decrease in PM10 when compared to the WFH period. When viewed from January 1, 2020, the comparison shows the same thing, at the time before and after EFH, the PM10 pollutant data shows relatively the same numbers in the previous period. Furthermore, PM10 monitoring in Jambi, Medan, and Indrapuri as well as in Banjar Baru Kalimantan, illustrating that the pollutant concentration was still relatively the same as the period before and after WFH. This means that population activities are still relatively the same in the area, climate and weather are not the only factors that can control the spread of the Covid-19 epidemic. From the results of research, the spread of the Covid-19 epidemic can be controlled by climate and weather factors, human demographics and mobility, and social interactions, and also determines public health interventions.

\section{CONCLUSION}

Climate or weather can affect the stability of the corona virus, which tends to be stable in the temperature range of $1{ }^{\circ} \mathrm{C}$ to $10^{\circ} \mathrm{C}$ which is classified as low temperature and low air humidity, namely $40 \%$ to $50 \%$. Indonesia, which is located on the equator, has an average temperature of 27 to $30 \mathrm{oC}$ with an air humidity of $70 \%$ to $95 \%$, which is an environment that is not ideal for the COVID-19 outbreak that spread in Indonesia in wave 2. This means that the human mobility factor has more influence on the spread of COVID-19. So it can be concluded that temperature and humidity factors can be supporting factors in reducing the risk of the spread of the Covid-19 outbreak. If efforts to limit the mobility of people / social interactions, as well as more intensive public health intervention efforts are implemented and enforced. Another thing that should be noted is the pollutants due to the mobility of people. Until June 2020 the intensity of pollutants is still the same as before the enactment of WFH, this means that restrictions on human mobility has not been effective. Based on the above conclusions, this study recommends efforts to limit people's mobility and social interaction more optimally so that weather factors can have a maximum effect on reducing the risk of the spread of the COVID-19 outbreak.

\section{REFERENCES}

[1] Sri Rahayu Pudjiastuti, Utilization of Forest Natural Resource Potentials, Especially Wood, to Realize Independence of Regional Development, Jour of Adv Reserarch in Dynamical \& Control System, Vol.12, Issue-02, 2020. 
[2] Sri Rahayu Pudjiastuti, Etika Lingkungan, Depok: Gemala, 2020

[3] Kimberly A. Nicholas, Jalur Emisi, Perubahan Iklim, dan Dampak di California, Prosiding akademi ilmu pengetahuan nasional 101(34), 12422-12427, 2004.

[4] Julia Pongratz, Emisi Karbon, dari penggunaan lahan dan perubahan tututapan lahan, Biogeosciences, 5125-5124, 2012

[5] Glen Peters, $\mathrm{CO}_{2}$ Diwujudkan Dalam Perdagangan Internasional dengan Implikasi Bagi Kebijakan Iklim Global, Sains \& Teknologi Lingkungan 42(5), 14011407, 2008

[6] Nadieh Bremer \& Shirley Wu, Data Sketches, Routledge, 1st Edition Published on September 17, 2020.

[7] Marsahll Burke, Memprioritaskan kebutuhan adaptasi perubahan iklim untuk ketahanan pangan pada tahun 2030, Sains 319 (5863), 607-610, 2008.

[8] Sri Rahayu Pudjiastuti, Improving Student (santri) care for the living environment in Nurul Huda Islamic Boerding School, Depok. JhSS Journal of Humanities and Social Studies, e-ISSN:2598-120X | p-ISSN:2598-117X. Sinta-3. Vol. 4, issue 1. Pages 01-04. 2020.

[9] Sri Rahayu Pudjiastuti, Sri Rumiati. Development of the PKn Learning Attitude Assesment Model in Foreign Political Culture and Results of PKn Learning from Students of Depok City Vocational School (SMK Semesta Cimanggis). JhSS Journal of Humanities and Social Studies, e-ISSN:2598-120X | p-ISSN:2598-117X. Sinta-3. Vol. 3, No.1. 2019.

[10] Pudjiastuti, Sri Rahayu, (2019). Penelitian Pendidikan. Media Akademi, Yogyakarta.

[11] Kompas.Com, Charles Darwin, Origin of Speciesby Means of Natural Selection, or The Preservation of Favpured Races in the Struggle for Life.Minggu 24 November 2019.09.WIB.

[12] Melanie Bannister Tyrrell, Senior Epidemology Consultant. https://www.ausvet.com.au

[13] Adhi Triatmojo, Periset/Coaction Indonesia dan Gabriela Claudia Kalalo, Koordinator Komunikasi/ Coaction Indonesia.

[14] Environmental News for a Healthier Planet and Life. https://www.ecowatch.com

[15] Araujo dan Naimi. 2020. BMKG on Twitter https://mobile.twiter.com

[16] Chen et al.(2011), Rapid Range Shifts of Species Associated With High Levels of Climate, https://www.researchgate.net

[17] Wang et.al(2020)Detection of SARS-CoV-2 in Different Types of Clinical Specimens, Published online:March 11,2020.doi:10.1001/jama.2020.3786

[18] Bannister-Tyrrell et. al. (2020), Pengaruh Cuaca dan Iklim Terhadap Pandemi COVID-19. 